\title{
THE IMPACT OF ECONOMIC FACTOR ON TRANSFORMING THE URBAN FORM OF ERBIL IN KURDISTAN REGION-IRAQ
}

\author{
DOI: 10.18485/arh_pt.2020.7.ch60
}

\author{
_ Rebaz Khoshnaw \\ Department of Urban Planning and Design, Csonka Pál Doctoral School, \\ Budapest University of Technology and Economics, 1111 Budapest, \\ Múegyetemrkp. 3. Building K II/93, rebaz.arch@yahoo.com
}

\begin{abstract}
The aim of the paper is to provide an insight of how the economic factor has influenced the urban structure and the urban form of Erbil city in northern Iraq. The escalation of urbanization in the past few decades resulted in dramatic increase of population. Moreover, after the Iraq War in 2003, the oil revenue helped the economic growth in the country especially in Erbil which was in a high security situation that attracted investors and individuals. The growth of economy in the city associated with growth of population, and it influenced the transformation of land use, transportation and real estates. The economic force was behind the increase in demand for land, densities, building heights as well as the change in land uses. Thus, all these factors collectively shaped structure of the city in a way that reflect the change of the economic growth of the city. New highway roads, new residential neighbourhoods have been constructed and high-rise buildings can be seen almost every were in the city. Yet, a prosperous city is not the one with higher economic growth, but the one, alongside with economic growth, provides the inhabitants with a better place to live in. Without a clear planning vision and well-prepared regulations, the economic factor (cost-benefit) will take the control of transforming the urban area of the city without consideration to the sustainability aspects. Here comes the institutional role, regulations and municipalities, to guide the investments and future developments to the right direction that serve the prosperity of the city.
\end{abstract}

KEYWORDS _ erbil, urbanization, land use, land economics, sustainability

\section{INTRODUCTION}

Today, $55 \%$ of the world's population lives in urban areas, a proportion that is expected to increase to $68 \%$ by 2050 , (United Nations, 2019). With this mass movement from rural to cities (trend of urbanization), the large cities are facing unprecedented transformation. Increasing populations of the cities means more needed residential units, more traffic and denser functions. Here comes the importance of land use, housing planning and regulations, as a framework to overcome the issue. Even though the land use arrangement can vary significantly depending on the function of a city, residential land use is the most common, occupying $65-75 \%$ of the surface of a city. Commercial and industrial land uses occupy $5-15 \%$ and $15-25 \%$ of the surface respectively, (Rodrigue, Comtois, \& Slack, 2017).

Erbil city (Figure 1), has witnessed different waves of urbanization prompted by the circumstances that Iraq and Kurdistan region have experienced such as Iraq-Iran war (1980-1988), the 2003s war and the crisis that followed which greatly affected the socio-economic status of the city. The Governorates of Erbil (Greater Erbil) with population over 1.8 million shows a high rate of urbanization (Figure 2). The aim of the paper is to understand the relationship between the growth of economy, 
urbanization and the transformation of urban form in the city. This will help municipalities and urban planners to act accordingly regarding the future growth of the city. Also, to adopt the necessary regulations to encounter further sprawl of the city.

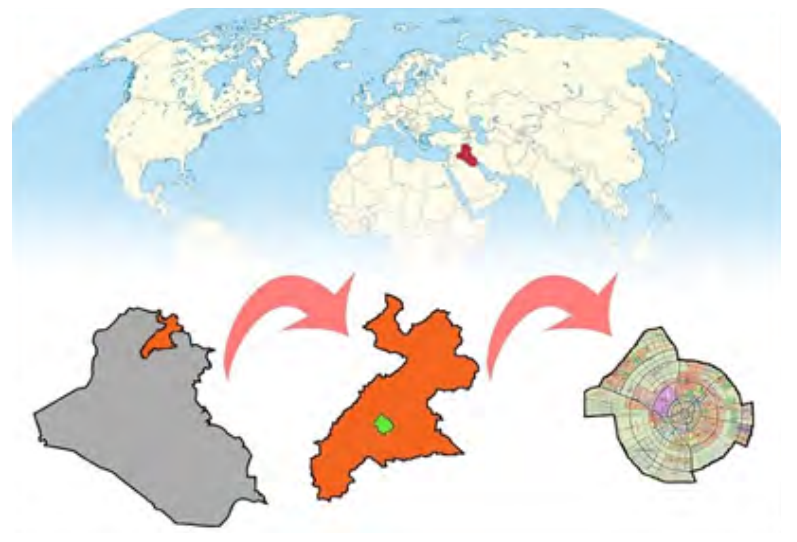

_Figure 1: The Location of Erbil City According to Iraq

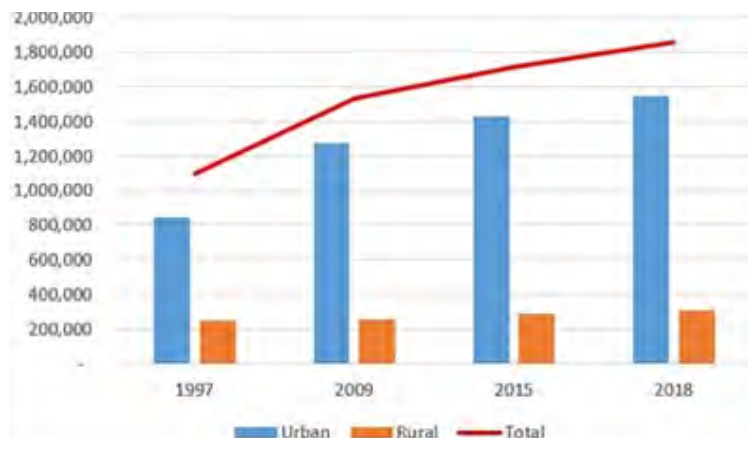

_ Figure 2: The Urban and Rural Population of Erbil Governorate (Source: Central Statistical Organization/ Iraq, 2017)

\section{METHODOLOGY}

The research is an attempt to provide understanding of how the economic growth is affecting the transformation of the urban form of Erbil at different levels. The research and the statistical data are focusing on the last twenty years. Because most of the growth has happened during this period of time especially after the year 2003. During this time, the expansion of the city and the increase of population was concurrent with the rapid economic growth. Yet, the transformation was not only affected the boundary of the city, but also reflected on the existing urban form as well. To understand these changes, multiple primary and secondary sources were combined in the process of investigation. The primary sources such as maps and satellite images were used. In addition, the demographic and statistical data were another source of information. Perhaps, using tools such as space syntax analysis software was an important part of the research. The literature reviews represent the secondary sources of information that support the analysis. 


\section{URBANIZATION AND THE CITY STRUCTURE}

The major force in shaping the environment is human activities, rather than nature, (Committee on Global Change, 1990). Historically, the land transformation has been caused by agriculture. Later on, the industrial revolution and its associated urbanization had taken the role. Today, the globalization of the world economy is causing further growth of population in the cities. Urbanization "perhaps the most significant influencer of real estate strategies in recent years" is not limited to labour migrations, but also includes the move of large companies, capital and investment, to cities (Pwc and The Urban Land Institute, 2017).

A United Nation's survey shows that the majority of decision makers discourage urbanization rather than welcome it. They would prefer to see people return to rural areas (Spence, 2009). However, urbanization is not only the result but also a cause of the economic development (Gallup et al., 1999).

Due to the great demand and unavailability of affordable houses, housing units turns into a commodity and a means of accumulating wealth that can be tradable and profitable for affluences and investors (UN News, 2017). Beside the availability of better services and easier access to amenities in cities, the economic aspect, especially job opportunities, is the key factor of migration from rural to urban. Thus, it is a major driving force of urban change. Urbanization is an unavoidable result of economic growth of cities, simultaneously a contributor to it. However, a better city is the city that functions better and provide higher quality of life for its inhabitants. Even though land use and transportation networks are very slow to change, their associated movements can change and adapt quickly. Housing are considered slow in changes as the buildings take several years from planning to completion. Whereas, population and employment are fast in changes (Wegener, 2004). This leads to disrupt the urban dynamics and for cities to not function efficiently.

Wegener shades light on these factors and their roles in transforming the cities and the systematic structure of these changes:

1. Land use: the generator and attractor of movements, it is the most stable component of urban dynamics, as changes are likely to modify the land use structure over a rather long period of time. Changes in the functional land use (economic nature of activities such as production, consumption, residence and transport) will affect formal land use that concerned with qualitative characteristics of space such as form and pattern.

2. Transport network: it is considered to be a rather stable factor, as the infrastructure are built for the long term. Changes in the transport network would impact accessibility and movements. Thus, more accessible street means more concentrated functions and consequently higher real estate prices.

3. Population and housing: They are the generators of movements, because residential areas are the sources of commuting.

\section{URBANIZATION AND HOUSING SECTOR IN ERBIL}

Being the capital city of Kurdistan region (with population of 850 thousand) and due to the safety and stability situation, the city of Erbil has attracted investment from other countries in Middle-East especially in construction field. In addition, opening Erbil's international airport in 2010 gave the city an opportunity of growth by connecting it with most of the cities in the Middle East and Europe. Both the economic growth and increasing population of the city has affected the demand for real estate projects in sectors of housing, commercial and hospitality.

Due to the decline in oil price in the mid of last decade and the political dispute between Erbil and Baghdad the construction activities have slowed down. Meanwhile, the growth of population continued due to the immigration from rural to the urban areas in addition to the IDPs who fled other Iraqi cities and sought shelters in Erbil. Thus, the real estate market in Erbil showed continuous increase 
due to the high demand (Figure 3,4).

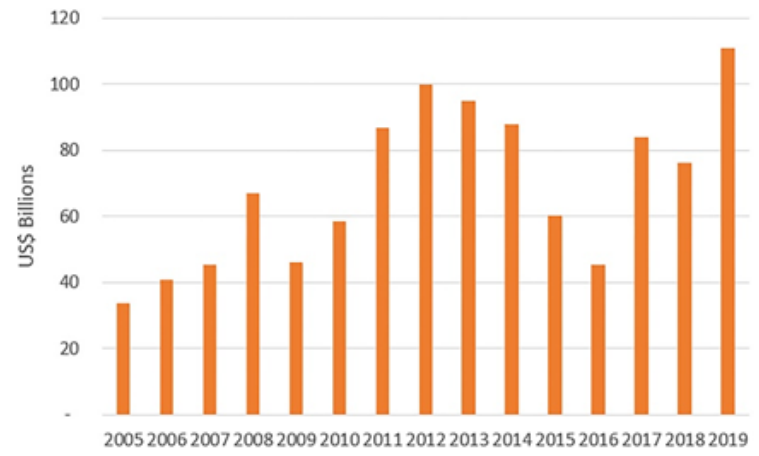

_ Figure 3: General fiscal budget of Iraq (Source of the data: Ministry of Finance-Iraq).

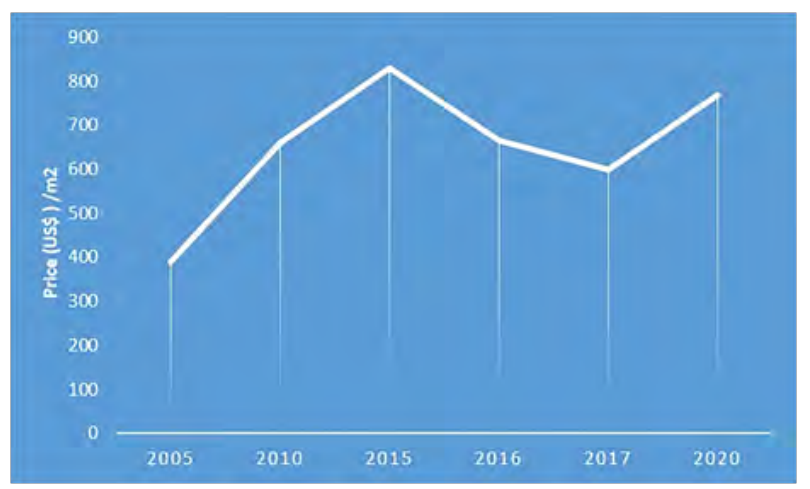

_ Figure 4: Average residential unit prices in Erbil, 2005-2020 (Source of the data: hajisalam real estate co.)

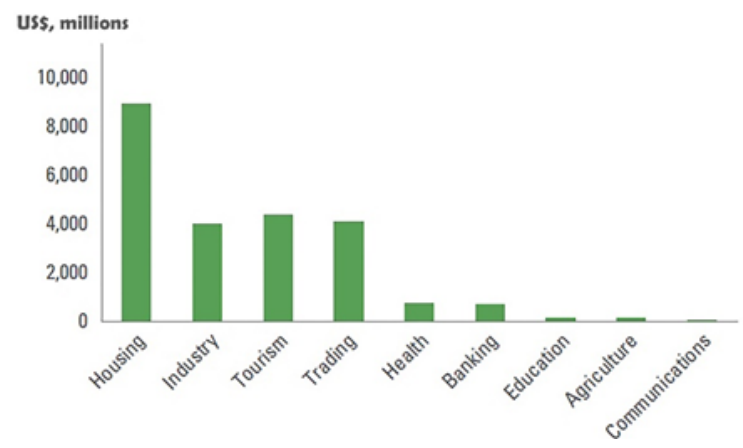

_ Figure 5: Erbil, Investments by sectors, 2006-2014 (Source: world bank)

Investing billions of US\$ in the housing sector during the last two decades in Erbil did not contribute in reducing the prices (Figure 5), because the larger portion of the capitals are invested in luxury units. In other words, the money is packed into a limited number of zones. Consequently, it caused scarcity in affordable houses and directly affects the liveability (pull force) of the city. None availabil- 
ity of affordable housing units has encouraged the phenomenon of plot divisions. In many districts the originally one house designed plot areas of $200 \mathrm{~m} 2$ or $250 \mathrm{~m} 2$ has been divided into two units. This practice has resulted in increasing the density and scarcity of amenities in these neighbourhoods (Figure 6a,6b).
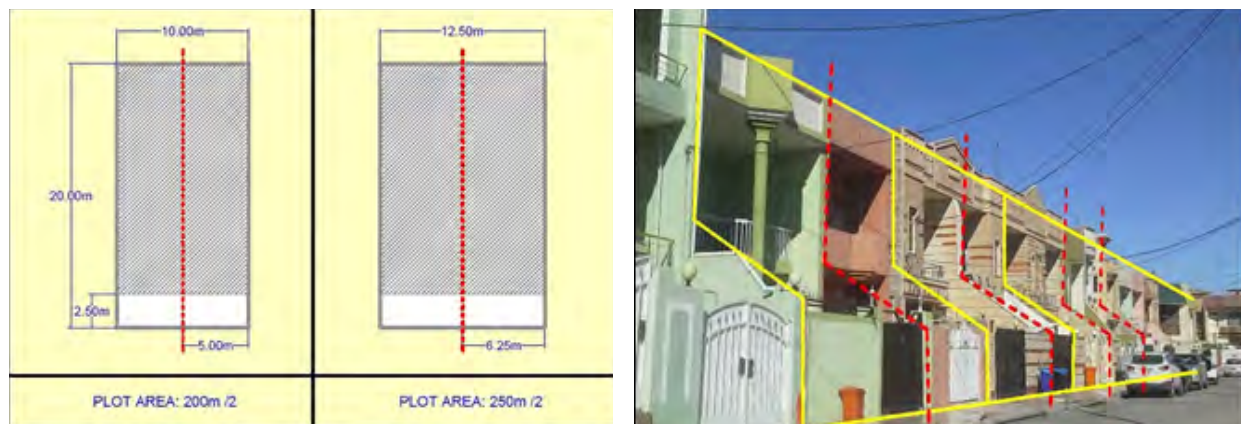

_ Figure 6a \& Figure: 6b: The practice of plot divisions in Erbil (Source: Author)

\begin{tabular}{|c|c|c|c|c|c|c|c|}
\hline$\%$ & $\begin{array}{l}\text { Whole } \\
\text { house }\end{array}$ & $\begin{array}{l}\text { Shared } \\
\text { house }\end{array}$ & $\begin{array}{l}\text { Apartment / } \\
\text { Flat }\end{array}$ & $\begin{array}{l}\text { Unfinished } \\
\text { Building }\end{array}$ & $\begin{array}{l}\text { Cabinet/ } \\
\text { Bungalow }\end{array}$ & $\begin{array}{c}\text { Formal collective } \\
\text { center }\end{array}$ & Tent \\
\hline KRI & 89.3 & 9.4 & 1.0 & 0.1 & 0.0 & 0.0 & 0.0 \\
\hline Rural & 97.1 & 2.5 & 0.1 & 0.2 & 0.1 & 0.0 & 0.0 \\
\hline Urban & 87.9 & 10.8 & 1.2 & 0.1 & 0.0 & 0.0 & 0.0 \\
\hline Duhok & 86.3 & 11.1 & 1.8 & 0.5 & 0.1 & 0.1 & 0.0 \\
\hline Erbil & 92.1 & 6.3 & 1.4 & 0.1 & 0.0 & 0.0 & 0.1 \\
\hline Sulaymaniyah & 88.4 & 11.2 & 0.4 & 0.0 & 0.0 & 0.0 & 0.0 \\
\hline $\begin{array}{l}\text { Camp } \\
\text { population }\end{array}$ & 0.3 & 0.0 & 0.0 & 0.0 & 12.6 & 24 & 63 \\
\hline
\end{tabular}

_ Figure 7: Shelter Type, (Source: UNFPA, demographic survey, Kurdistan region of Iraq, 2018)

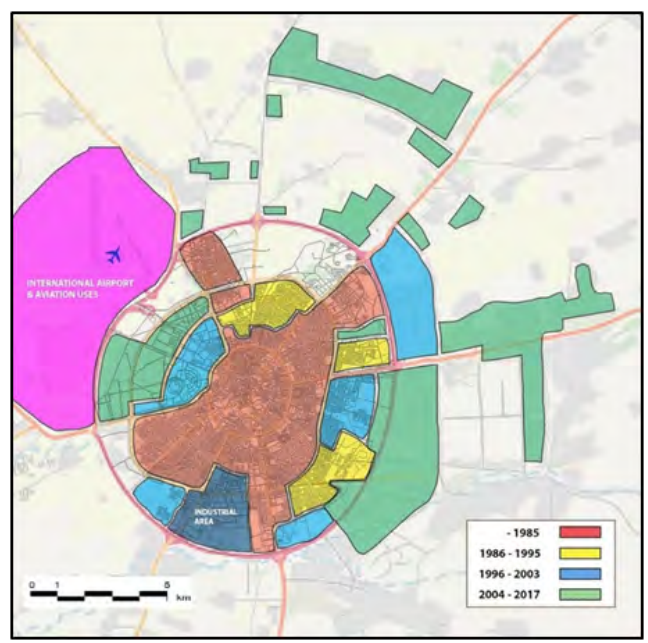

_ Figure 8: Growth of Erbil city (Source: drawing by the Author based on the data from Ministry of Municipalities-KRG). 
Another factor that affected the increase demand on residential land use in Kurdistan region and Erbil is the tendency of the families, in both rural and urban areas, to live in private houses rather than shared ones or flats. The majority of shelter types in Erbil are single household (92.1\%), while the families who live in apartment flats are just (1.4\%), (Figure 7 ). This fact imposed the change in land use from agriculture to residential which caused an urban sprawl (Figure 8). with all its subsequent negative results on traffic, air quality, social equity and the city's infrastructure.

\section{LAND ECONOMICS}

Cities are dynamic entities and their physical form is constantly changing to reflect the underlying economics of land use markets (Jones et al., 2010). We can describe land use as a market, where different urban activities are competing for land usage at a specific location (Rodrigue, Comtois, \& Slack, 2017). It is strongly based in the market principle of competition. The more desirable the location, the higher the rent value would be (Lipsey \& Chrystal, 2003). Land use is determined by the rent-paying capability of different functions in urban areas, such as retailing, industry and residence. The activity that affords the higher rent would get the best place (Verheye, 2009). This competition for land varies with the access to the land, the more accessed lands will have the highest prices. Thus, the price of land reaches the peak in the urban areas and subsequently influence the land use type. Usually, that high land value means more intensive usage of space, so the highest number of activities can benefit from central locations. The space syntax analysis of $60 \mathrm{~m}$ ring street in Erbil, which surrounds the inner city, shows a high level of connectivity and integration, (Figure 9a,9b). The integration measure shows the level of integration and segregation of each street according to the system. Higher level of integration of a street means it is easier to reach. On the other hand, connectivity measures the number of spaces immediately connecting a space of origin. It is worth mentioning that the properties of this street were residential up until 1990s with a few shops. The high level of accessibility and the demand on commercial lands on both sides of the street has changed the land use from residential to commercial. In other words, due to the high level of accessibility the real estate force has changed the land use, shape, density and the heights of the buildings.
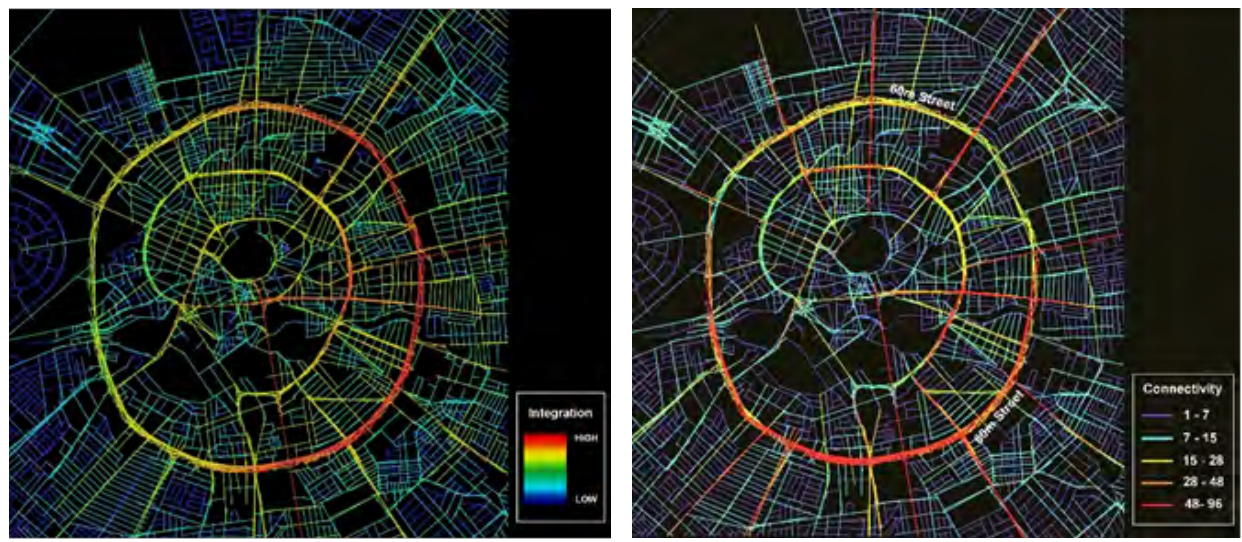

_ Figure 9a: Space syntax analyses, Integration axial map \& Figure 9b: Space syntax analyses, Connectivity axial map (source: Produced by the Author)

\section{DISCUSSION AND CONCLUSION}

Capital and financial support is the engine for improving urban areas. However, in the long term it my 
hurt the city system. Also, job opportunities might lead to other problems such as over population. Therefore, demand on land will increase and unoccupied areas within the city begins to be filled. Consequently, availability of land will decrease and real estate prices will rise. This phenomenon can be seen clearly in the case of Erbil city, as an example of a fast-growing city in a developing country. Due to the lack of appropriate planning vision and because of the absence of efficient regulations, land use changes in Erbil has been affected mainly by economic forces rather than planning strategies. Subsequently, the negative aspects of urbanization are obvious in the city such as urban sprawl, lack of services, and social inequality.

The research has identified three aspects of transformation in Erbil of how the economic and population growth has influenced the urban form of the city

1. At a city scale, it caused an urban sprawl. The expansion of the city was on the expense of agriculture lands. Consequently, it is affecting the air quality also adding a financial burden to supply the new neighborhoods with services and infrastructure.

2. In the absence of effective regulations, the real estate prices are transforming the functional and formal land use of the city.

3. At a neighborhood scale, the none affordable prices of residential lands have influenced the trend of plot divisions, which resulted in overcrowded neighborhoods and lack of services.

To avoid such consequences, the local government should plan a future vision for efficient distribution of land uses. Also, for a successful land use planning and active regulations, the economic factor should be taken in to consideration. In addition, it is of paramount importance for local government to ensure that the investment and allocation for developments has been done with taking sustainable growth into account and focusing more on affordable housing units for low-income families.

\section{REFERENCES}

_ Committee on Global Change. 1990. Research Strategies for the U.S. Global Change Research Program. National Academy Press, Washington, DC.

_ Gallup, L., Mellinger, D. and Sachs, D. 1999. "Geography and economic development." International Regional Science Review 22, no. 2: 179-232.

- Jones, C., Leishman, C., MacDonald, C., Orr, A. and Watkins, D., 2010. "Economic Viability" In Dimensions of the sustainable city. edited by: Mike Jenks and Colin Jones, 145-162. London: Springer.

_ Lipsey, R. \& A. Chrystal. 2011. Economics. 12th eds. Oxford University Press. New York.

_ PwC and the Urban Land Institute. 2017. Emerging Trends in Real Estate, Europe 2018. London: PwC and the Urban Land Institute.

_ Rodrigue, J., Comtois, C., \& Slack, B. 2017. The geography of transport systems. London: Routledge, Taylor \& Francis Group.

- Spence, M. 2009. Urbanization and growth. Washington, D.C.: World Bank, Commission on Growth and Development.

_ UN News. 2017. "Financial speculation led to unsustainable global housing crisis." Last modified March 3, 2017. Accessed February 27, 2020. https://news.un.org/en/story/2017/03/552492-financial-speculation-led-unsustainable-global-housing-crisis-un-expert-says

_ United Nations, Department of Economic and Social Affairs, Population Division. 2019. World Urbanization Prospects: The 2018 Revision (ST/ESA/SER.A/420). New York: United Nations.

_ Verheye, W.H., 2009. Land Use, land cover and soil sciences, Volume III: Land Use Planning fifth ed. EOLSS Publications, Oxford.

- Wegener, M. 2004. "Overview of Land-use Transport Models." In Transport Geography and Spatial Systems; Handbook 5 of the Handbook in Transport; Pergamon/Elsevier Science: Kidlington, UK, 2004; pp. $127-146$. 